\title{
Ekonomi Politik Bahasa Penyiaran di Jaringan Radio Prambors Rassisonia Indonesia
}

\author{
Bonaventura Satya Bharata dan Dina Listiorini \\ Dosen Ilmu Komunikasi FISIP - Universitas Atma Jaya Yogyakarta
}

\begin{abstract}
Abstrak
Tulisan ini berangkat dari penelitian mengenai bagaimana proses konstruksi bahasa siaran yang digunakan di industri radio siaran di Indonesia (khususnya di jaringan radio Prambors Rassisonia) tidak dapat dilepaskan dari logika kapitalisme. Penerapan kapitalisme di industri media biasanya melahirkan penyeragaman pada isi siaran, termasuk di dalamnya adalah bahasa dan cara bertutur. Namun dalam kasus jaringan radio Prambors yang beroperasi di daerah, seperti di Yogyakarta dan Solo, seringkali pengelola media harus melakukan kompromi untuk turut menyertakan bahasa-bahasa lokal (kosa kata dan dialek) digunakan dalam proses siaran. Akan tetapi diijinkannya penggunaan bahasa-bahasa lokal ini tetap dimaksudkan untuk mendekatkan diri dengan para pendengarnya yang tidak lain merupakan pasar dari radio Prambors Rassisonia.
\end{abstract}

Kata kunci: posisioning, logika kapitalisme, ekonomi politik media, dan Jakartacentris

\begin{abstract}
This article begin from the research of how the language be used in the broadcast radio industry in Indonesia (especially in the radio network Pramboprs Rassisonia) can not be separated from the logic of capitalism. Operational of capitalism ideology in the media industry generally produce uniformity in the media message, including the language and how to speak. But in the case of Prambors radio network which operating in the region, such as in Yogyakarta and Solo, media managers often have to make compromises to include local languages (vocabulary and dialect) be used in the broadcast process. But in allowing the use of local languages is still intended to be closer to his audience which is nothing but a market of radio Prambors Rassisonia.
\end{abstract}

Key words: positioning, capitalism logic, media political economy, and Jakartacentris

\begin{abstract}
Pendahuluan
Dunia media penyiaran Indonesia secara kuantitas berkembang pesat terutama pasca Reformasi. Jika pada masa akhir Orde Baru tercatat jumlah penyelenggara radio siaran swasta mencapai 516 buah, maka pada tahun 2003 lalu tercatat sudah mencapai 773 buah (Cakram, 2003, 34). Diyakini jumlah ini terus meningkat sampai dengan awal tahun 2006. Hal serupa juga berimbas
\end{abstract}

pada Yogyakarta. Saat ini tercatat 52 radio swasta gelombang FM yang mengudara. Padahal ketika Orde Baru berkuasa, di Yogyakarta hanya terdapat 16 stasiun radio swasta komersial.

Perkembangan dunia media penyiaran Indonesia, khususnya adalah radio siaran swasta komersial, tidak hanya dapat dilihat dari sisi kuantitas saja. Perkembangannya pun terasa mengesankan dari sisi kualitas. 
Penggunaan teknologi informasi dan komunikasi yang sangat maju, turut mengiringi perkembangan industri radio siaran yang ada. Konvergensi media antara radio dengan teknologi informasi dan komunikasi, mampu menciptakan apa yang dinamakan radio online atau biasa dikenal dengan audio streaming. Dengan teknologi ini, siaran radio yang tidak hanya dapat dinikmati pada lingkup lokal, namun juga dapat dinikmati secara global oleh seluruh dunia. Contohnya, siaran audio streaming oleh Radio Suara Surabaya yang tidak hanya dapat dikonsumsi oleh pendengarnya yang berdomisili di Surabaya, namun bisa juga dinikmati dari Jakarta, Medan, Makassar, bahkan Bangkok, Manila, sampai dengan Paris dan Los Angeles (Cakram, 2003, 8).

Konsekuensi logis dari perkembangan yang pesat di sisi kuantitas dan teknologi media penyiaran ini adalah kompetisi yang kian ketat di antara pelaku penyiaran radio itu sendiri. Hal yang wajar sebenarnya, mengingat perkembangan ini terjadi di tengah pertumbuhan ekonomi yang relatif belum stabil pasca krisis ekonomi 1997. Dari sisi kuantitas, perkembangannya demikian fantastis namun dukungan pertumbuhan ekonomi tidak berhasil mengimbangi perkembangan tersebut. Selain itu, kompetisi yang harus dilalui oleh industri radio tidak hanya datang dari industri sejenis. Perkembangan industri televisi yang pesat, turut memperketat situasi dan kondisi kompetisi ini. Hal ini terlihat secara jelas pada belanja iklan radio. Dari Media Scene yang dikeluarkan oleh Persatuan Perusahaan Periklanan Indonesia (PPPI) diketahui, bahwa meskipun secara kuantitas belanja iklan radio meningkat dari tahun ke tahun, namun secara persentase keseluruhan, belanja iklan radio menunjukkan tren penurunan yang berarti. Ini berbeda jauh dengan belanja iklan televisi, yang cenderung meningkat setiap tahun (Media Scene 2004-2005, 2005: 39).

Melihat kenyataan ketatnya kompetisi dalam industri seperti ini, penting kiranya para pemain di industri radio siaran untuk berpikir keras dan kreatif untuk meminimalisir situasi dan kondisi kompetisi itu sendiri. Di sinilah perlunya para pemain berpikir tentang segmentasi dan posisioning. Bila mengadopsi dari konsep ekonomi, maka yang dimaksud dengan segmentasi dalam industri radio dapat berarti bagaimana radio yang bersangkutan memilih secara selektif satu kelompok pendengar dari sekian banyak kelompok pendengar yang ada, untuk menjadi target pendengar dan mau menerima siaran dari radio yang bersangkutan (http://www.uiowa.edu/ commstud/adclass/ adage-positioning. html, diakses 20 Maret 2006). Posisioning radio (radio positioning) adalah karakter yang khas dari radio yang bersangkutan sehingga radio tersebut dapat dibedakan dengan radio yang lainnya. Jadi secara sederhana posisioning radio berarti sejauh mana radio tersebut mampu tampil dengan karakter yang khas dan berbeda sehingga target pendengar yang dituju mampu dengan mudah membedakan radio tersebut dengan radio lain (http:// www.determan.net/Michele/mposition. htm, diakses 20 Maret 2006).

Selain itu penting kiranya para pemain industri radio siaran swasta komersial untuk menyimak pendapat dari Alan B. Albaran (dalam Herawati dan Budi, 2005, 3), bahwa industri radio siaran memiliki struktur pasar yang monopolistic competition yang ditandai dengan : (1) Adanya beragam jenis radio yang menyajikan program siaran yang hampir sama, namun antara satu dengan 
yanglain tidak dapat saling menggantikan (substitute) dengan sempurna. Meskipun ada kesamaan format, namun tetap ada perbedaan, misalnya dalam gaya bicara penyiar, fasilitas teknis yang tersedia, serta audiens yang dituju. (2). Masing-masing stasiun radio berusaha mempunyai ciri khusus agar dapat dibedakan dengan stasiun radio yang lain oleh pendengarnya dengan berbagai ragam cara. Antara lain dengan promosi dan periklanan. Berangkat dari penelitian F. Anita Herawati dan Setio Budi mengenai ekologi media ini, menunjukkan bahwa di Yogyakarta, dengan hadirnya demikian banyak radio siaran swasta komersial telah memicu kompetisi yang sangat ketat, namun karena kemudian masing-masing radio siaran melakukan penajaman segmentasi pendengar dan posisioning radio, sedikit banyak kompetisi masih dapat diminimalisir.

Penajaman segmentasi pendengar dengan demikian merupakan kebutuhan logis untuk melakukan strategi bisnis bagi industri radio siaran swasta komersial. Dari kondisi ini maka muncullah radioradio dengan beragam segmen pendengar seperti radio professional muda atau radio eksekutif muda, radio anak muda, radio remaja, radio wanita, dan lain-lain. Bila penentuan segmentasi pendengar sudah dilakukan tentu perlu kemudian diikuti dengan posisioning radio. Posisioning radio dapat muncul dalam bentuk gaya siaran, misalnya jenis lagu atau musik yang dipilih, jenis informasi yang akan disampaikan, dan yang tidak kalah penting adalah gaya dan bahasa penyiaran yang dibawakan oleh penyiar dalam berbicara dengan pendengarnya. Di sisi lain penajaman segmentasi dan posisioning radio ini juga memudahkan produsen ataupun perusahaan periklanan yang hendak melakukan promosi di radio ini. Karena segmentasi pendengar yang tajam dan posisioning radio yang jelas ini tentu memudahkan produsen atau perusahaan periklanan untuk mengidentifikasi apakah produk yang hendak dipromosikan cocok apabila diiklankan melalui radio yang bersangkutan.

Kebanyakan stasiun radio swasta komersial sering memilih kelas menengah atas sebagai target segmen pendengarnya. Hal yang wajar sebenarnya karena produsen atau perusahaan periklanan yang ingin berpromosi melalui media ini, tentu menuntut penyelengara radio swasta komersial untuk memiliki pendengar dengan daya beli yang kuat. Harapannya adalah produk yang diiklankan kemudian dibeli oleh khalayak dari media radio yang bersangkutan. Kelas menengah atas tentu kemudian menjadi jawaban atas tuntutan ini karena kelas menengah inilah yang memiliki daya beli yang kuat sebagai modal awal sebuah sasaran promosi.

Anak muda adalah salah satu segmen yang cukup potensial bagi industri radio untuk dijadikan khalayak pendengar. Anak muda dengan kategori usia 13-22 tahun dari kelas menengah adalah sasaran yang secara komersial menguntungkan. Hal ini dapat dicermati dari banyaknya iklan atau media massa yang diperuntukkan bagi mereka. Pemilihan ini tentu bukan tanpa alasan, mengingat segmen pendengar anak muda dari kelas menengah atas merupakan segmen pendengar yang seksi sehingga banyak diperebutkan (Majalah Cakram, 2005).

Salah satu bentuk posisioning yang digunakan untuk membedakan karakter satu radio dengan yang lain 
adalah melalui bahasa siaran. Bahasa siaran yang digunakan antara radio yang memiliki segmen pendengar eksekutif muda dengan radio yang memiliki segmen pendengar anak muda tentu akan sangat berbeda. Radio dengan segmen pendengar kalangan eksekutif atau "the oldies" cenderung memiliki bahasa siaran yang rapi, teratur, sesuai dengan kaidah tata bahasa yang baku. Demikian pun dengan radio yang memiliki segmen pendengar anak muda, akan dibedakan lagi berdasarkan karakteristiknya. Anak muda yang dimaksud apakah yang berusia belasan tahun (teenager) atau anak muda yang berusia menjelang dewasa seperti mahasiswa. Sekali lagi, karena keduanya memiliki karakteristik yang berbeda tentunya juga akan memiliki bahasa siaran yang berbeda pula. Namun yang jelas bahasa siaran ini turut memperkuat identitas radio menuju pada posisioning yang diinginkan.

Adapun beberapa contoh bahasa siaran yang sempat direkam pada masa pra penelitian :

Radio Prambors Rasisonia Yogyakarta (95,8 FM) pada Minggu, 26 Maret 2006, pk 14.00 WIB :

95,8 FM Prambors Rasisonia .... song taken from album Eighty Milimeter ... Nobodys Does It Better ... original soundtrack dari Mr. and Mrs. Smith .... film yang dibintangi Bradd Pitt dan Angelina Jolie .... yang akhirnya juga mempertemukan mereka dan akhirnya juga membuat mereeeka saling ... falling in love .... Aauwww ... Di satu sisi kaya'nya mereka emang lucu banget dech .... Dua-duanya lucu banget dech .... Dua-duanya adalah simbol the sex appeals people alive .... All right guys back to ......

Radio Trijaya Network Yogyakarta (97,00 FM) pada Minggu, 26 Maret 2006, pukul 14.30 WIB:

Baik professional muda ... lagu pilihan pertama kita di sessi Buy One Get One Free kita sore kali ini .... Ada Cindy yang pernah kuliah di Amerika ... kemudian juga di album terbarunya ini ... dia berhasil menggaet beberapa musisi papan atas Indonesia ... ada Glenn Fredly juga yang sempat berkolaborasi dengannya di lagu Rintangan ya ... lagu lama yang sempat dinyanyikan oleh Lydia Noorsaid ..... Okey ... dan lagu pilihan kedua professional muda .... Ada Rossa dengan Cintai Daku ......

Dari contoh bahasa siaran yang digunakan tersebut dapat dilihat bahwa ada kekhasan tersendiri dari bahasa siaran yang digunakan oleh Radio Prambors Rasisonia sehingga berbeda dengan yang digunakan oleh Radio Trijaya Network. Walaupun sama-sama dalam acara pemutaran lagu berdasarkan permintaan pendengar, namun bahasa siaran keduanya sangat jauh berbeda Ini terjadi karena perbedaan segmen pendengar dari kedua radio tersebut. Walau sama-sama memfokuskan pada kelas menengah atas, Radio Prambors mengambil segmen pendengar anak muda, sedangkan Radio Trijaya mengambil segmen profesional atau eksekutif muda. Bahasa siaran di Radio Prambors Rasisonia dibawakan secara tempo yang cepat sedangkan di Radio Trijaya dibawakan dengan tempo sedang.

Penelitian Dina Listiorini (1994) menunjukkan bahwa radio-radio bersegmen anak muda di Surabaya cenderung menggunakan bahasa siaran dengan mereproduksi bahasa pergaulan anak muda yang berkiblat pada bahasa anak muda Jakarta. Penggunaan ini juga menunjukkan adanya standardisasi bahasa siaran yang digunakan pada 
radio-radio anak muda di Surabaya.

Prambors Rasisonia adalah salah satu media radio yang bermain pada sasaran atau segmen pendengar anak muda. Radio Prambors Rasisonia merupakan radio yang memiliki jaringan siaran di beberapa kota besar di Indonesia, seperti Jakarta, Semarang, Yogyakarta, dan Makassar. Radio ini juga membidik pendengar dari kalangan anak muda dari kelas menengah ke atas. Tentunya bahasa yang digunakan oleh Prambors adalah bahasa yang digunakan anak muda pada segmen yang diraih. Penggunaan bahasa ini akan tentunya akan tetap dipertahankan di tingkat manajemen Prambors untuk dilaksanakan dijaringanjaringan Prambors di berbagai kota di seluruh Indonesia. Dengan kata lain, para penyiar radio jaringan Prambors di seluruh Indonesia akan mempertahankan penggunaan bahasa anak muda "ala Prambors" tersebut.

Konsekuensi pemilihan target pendengar ini bagi radio tentu berimbas pada posisioning radio yang bersangkutan. Seperti yang telah disebutkan di atas, posisioning radio secara operasional dapat muncul dalam gaya siaran, yakni misalnya jenis lagu atau musik yang dipilih, jenis informasi yang akan disampaikan, dan yang tidak kalah penting adalah gaya dan bahasa siaran.

Dari penjelasan sebelumnya dapat diketahui bahwa perkembangan radio siaran di Indonesia sudah masuk pada ranah industri, yang dapat dilihat dari karakteristiknya berupa adanya kompetisi, penggunaan teknologi, segmentasi pendengar dan posisioning radio. Karakteristik ini pada akhirnya bermuara pada berlakunya inti dari logika industri dalam sistem kapitalisme (seperti yang dialami Indonesia mulai dari masa Orde Baru sampai dengan sekarang) dalam perkembangan radio siaran di Indonesia. Dengan demikian untuk melihat fenomena penggunaan bahasa siaran anak muda seperti yang terjadi di jaringan Radio Prambors Rasisonia, dari segi produksi industri, harus dilihat latar belakang logika industri kapitalisme dari fenomena tersebut.

Dalam logika industri pada sistem kapitalisme, dinyatakan bahwa segala sesuatu yang dimiliki oleh pemilik modal, dapat menjadi alat produksi untuk mendapatkan keuntungan. (Muawiyah; 2000, 58). Jadi dalam dunia industri, seperti halnya dengan industri radio siaran komersial di Indonesia, modal yang secara operasional berwujud stasiun radio beserta perlengkapannya berupa peralatan berikut sumber daya manusia yang ada di dalamnya (termasuk penyiar di jaringan Radio Prambors Rasisonia) merupakan alat-alat produksi, yang dapat dimaksimalkan untuk mencapai keuntungan. Oleh karena itu perlu adanya penguasaan terhadap alat-alat produksi tersebut. Bagaimana ini dicapai, khususnya penguasaan terhadap sumber daya manusia?

Logika sistem kapitalisme tidak perlu melakukannya dengan kekerasan, namunini dilakukan dengan menciptakan situasi dan kondisi yang akhirnya akan memunculkan ketertundukkan sukarela. Ini dimaksudkan agar para sumber daya manusia di industri ini, termasuk di dalamnya penyiar sebagai garda depan industri penyiaran radio, secara tidak sadar akan berperilaku sesuai dengan nilai-nilai yang dikehendaki sebelumnya. Sehingga ketika melakukan siaran, penyiar mampu melaksanakan apa yang menjadi kehendak logika kapitalisme dalam industri radio siaran 
swasta komersial, termasuk di dalamnya memiliki perilaku yang sesuai dengan logika tersebut, yakni menggunakan bahasa siaran yang sekiranya akrab dalam benak pendengarnya. Adanya pola tertentu dalam bahasa siaran anak muda di jaringan radio Prambors Rasisonia ini juga dijelaskan dengan menggunakan logika kapitalisme pula. Sebab pola tersebut tentu tidak dapat terlepas dari logika kapitalisme yang melatarbelakangi produksi dari industri radio yang bersangkutan. Demikian pula dengan keputusan manajemen dan penyiar yang menggunakan bahasa siaran tersebut di seluruh jaringan radio Prambors di seluruh Indonesia.

Bila pada penelitian Listiorini (1994) menguraikan bagaimana sebuah bahasa siaran di radio anak-anak muda di Surabaya diproduksi dan di reproduksi, maka penelitian ini lebih memperhatikan pada tingkat organisasi radio yang memproduksi dan mereproduksi bahasa siaran anak muda di radio Prambors.

Dengan demikian, dari seluruh uraian yang telah dikemukakan, dapat disimpulkan bahwa tulisan ini ingin melihat dua hal, yakni (1). Bagaimana bahasa siaran anak muda di jaringan radio Prambors Rasisonia digunakan dan dipertahankan oleh manajemen dan penyiar Prambors di seluruh jaringan Prambors? dan (2). Bagaimana proses pembentukan bahasa siaran anak muda di jaringan Radio Prambors sebagai bagian dari posisioning industri radio yang tidak terlepas dari logika kapitalisme?

\section{Bahasa Siaran di Radio Prambors}

\section{Konsep Radio Anak Muda dan Pengaruhnya pada Isi Siaran}

Sejak berdirinya, Prambors menetapkan bahwa yang dimaksud dengan radio anak muda bagi Prambors adalah radio yang mampu membawa dirinya sebagai teman bagi pendengarnya. Anak muda yang disasar Prambors pun adalah anak muda yang gesit, kreatif, dan jujur. Dengan demikian Prambors menempatkan dirinya sebagai radio yang mampu memberikan informasi sesuai dengan kebutuhan anak muda sekarang.

Oke .... Pertama, bukan hanya radio anak muda aja kali ya..seluruh radio barangkali ya..itu sebetulnya karena radio bagi anak muda menjadi teman. Karenanya, kenapa dia tidak bisa dikalahin 100\% sama I-Pot atau $C D$, karena di radio ada sosok manusianya disitu ya. Penyiar atau DJ juga menjadi teman. Beberapa riset kita yang dilakukan internal ataupun yang menulis skripsi bilang kalau radio Prambors itu teman yang kasih informasi. Ya pastinya ... bukan informasi tentang apa namanya hal - hal yang berat yang sifatnya nasional, politik, apa ekonomi atau apa... Informasi aja yang menyangkut aktivitas anak muda ... ada event dimana, si ini anaknya gimana, di SMA anu, atau di kampus mana gitu ya... Sesuatu yang memberi bahan untuk dia bergaul, bersosialiasi sama teman - temannya. Kan malu anak muda kalo ada event di Ancol khan malu misalnya Fault Out Boy band yang ngetop itu datang, dia sampai tidak tahu. Prambors sebagai nara sumber yang memberitakan. Jadi sumber informasi udah disebutin. Kawan apa sih fungsinya ? Loe berguna misalnya kalo loe kasih tahu gue sesuatu ... Begitu kan ? Yang kedua curhat. Jadi radio buat anak muda itu ada dua, informasi tentang sesuatu dan teman curhat ... saling sharing. Yang namanya sama kawan, saya sama Mbak Dina sama Mas Bonna khan bisa saling sharing sesuatu. Sebetulnya itu mbak dan aku pikir semua radio juga kayaknya akan menjalankan fungsi itu, ya. (Wawancara dengan 
Bu Nia Soewardi, Direktur Jaringan Prambors Jakarta)

Namun karena radio yang memiliki segmen anak muda tentunya bukan hanya Prambors, maka Prambors mencoba mempertajam segmen pendengarnya menjadi anak muda dalam rentang usia 14-25 tahun dan masuk dalam kelas $A B$ (dalam perhitungan AC Nielsen) dengan gaya hidup yang sadar teknologi (melek internet dan gadget misalnya), tidak perlu memiliki kekayaan namun selalu mengaktualkan informasi yang dimiliki.

Dari sejak kita berdiri intinya sebetulnya ini koridornya. Jadi anak muda yang lima belas sampe dua puluh empat tahun, kelas menengah atas, kalau di AB-Class ya..kalau gak salah ya..aku lupa expenditurenya ya dua koma tujuh setengah kali ke atas.. ..Saya lupa sekarang berubah indikatornya kan seperti itu ... Sebetulnya kalo ikut AC Nielsen itu expenditurenya ya seperti tadi, kalo standarnya paling kecil satu juta atau satu koma tujuh lima. Ya, jaman sekarang sedikit ya buat orang kebanyakan gitu. Kemudian gaya hidupnya. Dia melek internet, dia melek gadget, tapi dia gak mesti punya mobil ya, tapi terus ter-update sama sesuatu (informasi). Hari ini kebendaan rasanya gak terlalu relevan ya, masih ada hal - hal lain ya yang bisa jadi indikatornya. Nah, sekarang naik motor kan tidak masalah ya. Kalo jaman dulu indikator motor menunjukkan kelas menengah dan bukan menengah atas. Indikator menengah atas biasanya mobil, ya.... Kalau sekarang tidak seperti itu ... Boleh saja ibunya karyawan bawahan, tapi kalo dia melek internet gimana ? Kalo dia senang main game gimana ... ? Orientasinya juga luas begitu ... bukan hanya cepat di kampungnya saja. Jadi ukurannya berubah ya. Kalau gak salah saya pernah dengar ada satu segmentasi demografi namanya media grafit (Atau apalah gak ngerti lha ya) Jadi, bagaimana mereka terakses sama media. Itu yang penting ya ! Sehingga mereka ter-update, kreativitasnya itu tanpa batas. (Wawancara dengan Ibu Nia Soewardi-Direktur Jaringan Prambors Jakarta).

Dengan demikian terdapat keunikan pada segmen pendengar radio Prambors, walaupun dalam perhitungan AC Nielsen masuk dalam kelas ekonomi $\mathrm{AB}$, namun secara riil pendengarnya juga melibatkan mereka yang memiliki gaya hidup melek teknologi dan informasi walau secara ekonomi berada di luar kelas ekonomi tersebut.

Dalam operasional siarannya, karena sasaran segmen pendengar yang dituju adalah anak muda, maka segala sesuatunya pun diracik dengan nuansa anak muda. Misalnya bahasa siaran dan pemilihan lagu. Bahasa siaran disesuaikan dengan masanya dan pemilihan lagu ditentukan oleh kepopuleran lagu tersebut di mata anak muda yang ada sekarang.

Balik lagi ke konsep awalnya kalo misalnya kita ingin bentuk radio anak muda, dengan segementasi radio anak muda, ini berkait dengan banyak hal. Pertama, konsep penyiaran. Apa air personalitynya yang akan dibangun dan lain segala macam. Itu nanti jatuhnya pada ornamen dan bahasa. Dari gaya bicara, dari trend yang sedang berjalan sehingga harus masuk ke dalam itu juga. Yang kedua adalah kita akan membicarakan mengenai lagu. Lagu yang diputar enggak mungkin juga dong lagu-lagu tua begitu. Meskipun ada segmensegmen khusus yang kita buat tapi penempatan lagu-lagu itu atau playlist itu disesuaikan dengan umur. Misalnya gini, sekarang umur gue sudah dua puluh lima tahun, nih. 
Pada umur dua puluh lima tahun ini saya masih masuk segmennya Prambors gitu. Segmennya Prambors adalah 14 - 25 A B. Jadi pada lagu jaman-jaman dulu saya pengen flash back lagi. Saya gaul pada saat kira-kira umur 15 tahun. Berjalan ke sepuluh tahun kebelakang. Tahun 2007 kalo ke 10 tahun kebelakang kan berarti tahun 97. tahun 97 adalah masa-masa jaya waktu itu dengerin radio gitu kan. (Wawancara dengan Annas, Program Director PramborsSolo)

\section{Penyiar, Bahasa Siaran, dan Sikap Manajemen Siaran}

Karena segmen pendengar Prambors adalah anak muda, penyiar yang dipilih pun juga dengan rentang usia yang muda. Dalam rekruitmen penyiar, Prambors mensyaratkan dari sisi usia maksimal adalah 23 tahun. Dengan demikian kiprahnya di radio Prambors akan bisa maksimal sekitar empat sampai dengan lima tahun berikutnya. Dalam proses rekruitmen, persoalan status sosial yang menyangkut kelas ekonomi ternyata tidak terlalu menjadi perhitungan dalam penerimaan. Persyaratan menjadi penyiar Prambors lebih ditekankan pada masalah kreativitas calon penyiar. Penyiar Prambors diharapkan adalah sosok kreatif. Dengan demikian, bisa saja calon penyiar Prambors datang dari status sosial kelas ekonomi menengah, namun calon memiliki kreativitas tinggi yang ditunjukkan lewat berkas lamaran yang dibuat secara unik sehingga menarik perhatian.

Pertama tentu saja untuk penyiar (DJ), demografinya usianya muda. Penyiar kami paling tua ketika direkrut itu 23 tahun ya.... Jadi 23 tahun, dengan asumsi mereka akan melewati masa pendidikan kira kira setahun sampai jadi ya dua puluh empat kalau cepat, ya masa panennya empat tahun lah. Jadi sebelum tiga puluh mereka sudah bisa membantu kita ngetop. Begitu ya ? Mereka juga bisa mengambil sesuatu dari kita. Syarat yang lain lagi, mereka harus kreatif. Saat ini kita sebetulnya lagi merekrut. Nanti Mas Bona sama Mbak Dina bisa lihat satu syarat yang kita terapkan untuk para pelamar adalah dengan membuktikan kreativitas. Tunjukkan kreativitas kamu dalam dalam bentuk lamarannya. Jadi jangan hanya biasa saja. Jadinya wah ... macam - macam. Ada yang bikin CD dengan film, ada yang bikin lamaran dengan bentuk sarang tawon. Segala bentuk kreativitas ala mereka. Jadi harus gak biasa. Nah ... selain mereka harus kreatif, mereka harus punya interest tertentu. Yang kami butuhkan mereka harus punya interest. Misalnya di organisasi, ya nah ... apa buktinya ? Ooo..dari kecil gue udah jadi ketua kelas, ketua OSIS ... atau apalah .. dan lain sebagainya ...Atau gue anak band atau gue anak design grafis ... atau apa ..penari.. dan sebagainya. Jadi kita gak mau anak yang biasa - biasa aja, yang gak punya sesuatu di-share kan ya ...karena menurut pengamatan kami, anak muda itu senang saling share, ya. Loe punya apa? Gue punya ini nih ... Ayo kita saling berbagi. Begitu ya ... ? Kalau mereka gak punya sesuatu, apa yang mau dishare ya ? Jadi harus punya sesuatu yang bisa dia share ke orang lain. Sedangkan untuk status soial ekonomi itu nggak, ya. Kalo di lamaran kan, susah kita buktikan ya. Memang ada indikator - indikator yang sangat teknis yang kayak feeling yang tidak bisa kita ungkapkan juga dalam promo. Misalnya cara dia mengungkapkan sesuatu, kelasnya akan beda ya ... Bener...begitu ya ... Misalnya cara dia menulis ... saya akan bertanya - tanya kalo ada lamaran yang bunyinya ... misalnya laki namanya... Ronny itu suka ini lho ... aneh khan cara berkomunikasi model begitu. Nihanak...anak seperti apa sih ? Terus dicermati fotonya... 
fotonya..itu kok gayanya tahun dua ribu awal ya ... ? Jadul banget ... dua ribu awal ya sudah jadul khan buat Prambors ya ... Gak banget deh ...orang lagi pake skin nya jeans, dia pake celana gombrang begitu ... Ini beda atau ketinggalan jaman, ya khan Bisa dibedakannya begitu. Jadi up to date itu harus. Jadi harus dapat sesuatu yang up to date. Kalo gak ... dia nggak bisa terus maju ngasih sesuatu yang baru ke pendengarnya ..Begitu.. ? Bahwa dia sukanya lagu - lagu eighties ya ... bukan berarti dia gak bisa terpilih tapi...eighties khan itu hanya salah satu interestnya tapi orientasinya dia yang seperti apa, gitu.. ke depannya ... (Wawancara dengan Ibu Nia Soewardi - Direktur Jaringan Prambors Jakarta)

Namun Prambors juga mengakui bahwa pemilihan karakter penyiar yang muda dan kreatif juga dilatarbelakangi oleh faktor tuntutan industri. Karena Prambors adalah radio siaran yang juga berorientasi pada bisnis. Kondisi ini sudah berlaku sejak Prambors berdiri. Walaupun pada mulanya pertimbanganpertimbangan yang diambil sering tanpa disadari sudah berorientasi pada bisnis. Artinya ada perhitungan untuk mendapatkan keuntungan dari setiap kegiatan yang dilakukan, termasuk dalam pemilihan penyiar sebagai ujung tombak siaran radio Prambors. Penyiar yang dipilih harus memiliki nilai jual yang tinggi. Pemilihan penyiar akan selalu disesuaikan dengan apa yang menjadi harapan pendengar radio Prambors itu sendiri.

Oke ya karena ini bisnis, tentu aja market yang kita pilih adalah market yang menjanjkan dalam arti akan meghasilkan uang. Kami dari awal berdirinya Prambors sebetulnya sudah memperhitungkan ini ... Walau barangkali dulu ilmu marketing para pendirinya belum kontemporer, tapi juga dengan feeling ya... Nah ... terus mereka lingkungannya anak orang kaya di Menteng, tentu aja siarannya untuk orang - orang yang mereka kenal. Ehmm...ya kok langkah pertama ini ternyata terlihat secara bisnis dampaknya bagus. Memang hari ini khan lagu dangdut yang menengah ke bawah itu gak laku. Jadi dari sekian banyak pilihan yang dipilih ...walau sifatnya intuisi, dari tahun ke tahun terbukti bahwa itu memang secara bisnis berhasil. Jadi ditetapkanlah segmennya itu. Nah, dari segmen itu, menuntut penyiar yang seperti apa? Seperti saya tadi bilang. Karena kami mencocokkan antara maunya si pendengar dengan apa yang kami sediakan. Penyiar yang dengan karakter itu sebetulnya adalah mengacu kepada maunya si pendengar. Mereka gak mau ditemenani sama orang yang сирu. Kok dia gak tau apa - apa sih ? Kalau begitu, gue gak dapet apa - apa nih (Wawancara dengan Ibu Nia Soewardi - Direktur Jaringan Prambors Jakarta)

Diakui pula oleh pengelola Prambors Solo, penempatan penyiar dalam melakukan siaran di radio Prambors tidak hanya ditentukan oleh harapan pendengar, namun ditentukan pula oleh para pengiklan. Pengiklan memiliki pengaruh yang cukup besar tentang siapa dan kapan penyiar ditempatkan dalam siaran di radio Prambors.

Kalau itu jelas sudah pasti. Misalnya begini saya menaruh penyiar Adia ... menaruh sang penyiar ini. Bukan hanya Adia nih, satu penyiar saya tempatkan di acara ini untuk bisa menyedot pendengar. Ini tentu dengan segala macem pertimbangan-pertimbangannya. Jadi acaranya mau di bentuk seperti apa dulu nih kalau misalnya acaranya sudah tahu seperti apa, maka pilihan penyiarnya ini akan menjadi pertimbangan penting. Saya 
nggak mungkin akan menaruh orang sembarangan di situ. Nah biasanya sudah berjalan seperti ini. Cuma untuk telkomsel itu gak mau penyiar lain selain Adia. Misalnya seperti itu kalau berkaitan dengan pasang iklan. Ya ... pasar iklan dan segala macem. Kalau pasar pendengar balik lagi, saya belum mendapatkan data yang faktual tentang ini semuanya gitu. (Wawancara dengan Annas Program Director Prambors Solo).

Satu yang unik dari Prambors adalah ternyata pertimbangan gaya bahasa siaran (misalnya : medok) ternyata bukanlah hambatan untuk diterima sebagai penyiar Prambors. Artinya penyiar Prambors, terutama yang berada di Prambors daerah bisa saja memiliki gaya bahasa siaran dengan dialek lokal dan ini bukanlah termasuk hal yang sangat mengganggu bagi berlangsungnya siaran Prambors sebagai radio anak muda. Dikatakan unik karena industri umumnya mensyaratkan adanya keseragaman untuk menjaga identitas lembaga. Jika ini adalah industri radio siaran, maka keseragaman gaya bahasa penyiaran bisa jadi juga menjadi persyaratan untuk menjaga identitas lembaga. Namun hal ini tidak berlaku secara kaku di jaringan radio Prambors.

Sebetulnya secara umum panduannya seperti itu kalau untuk para penyiar. Cuma memang jaringan ini baru, ya ... Saya dengar di Jogja tidak cocok. Pendengar pernah bilang : Eeh ... loe kok Jakarta banget ya ..memang pendengar loe asyik dengerin loe gitu.? Ternyata penyiar yang direkrut anak - anak Jakarta. Akhirnya yang paling cocok kan adalah orang yang bisa memainkan berbagai dialek ya. Penyiar bisa sebagai orang lokal, dia bisa berbahasa Indonesia yang baik dan benar, tapi untuk kata-kata tertentu dia pakai dialek lokal supaya bertambah keakrabannya. Sekarang setelah saya ngomong gitu, berusaha dia sok - sok Jogja, ternyata itu nggak pantas. Jadi terutama di Jogja jadi kami merasakan ada problem karena yang kita rekrut kemarin adalah anak - anak Jakarta. Nah sekarang strategi dirubah ... kita rekrut anak asli Jogja tapi yang bisa berbahasa Indonesia dengan baik dan benar tapi tidak kehilangan dialek daerahnya ... Begitu ya ... ? Jadi dia bisa padu padan dengan pendengar Jogja. Di Makassar kita melakukan itu berhasil ya ... Di Makassar malah lebih hebat. Ada penyiar yang bisa berbahasa Indonesia tentu aja ya... kemudian bahasa Makasar pasti, bahasa Arab, Bahasa Inggris..gitu. Jadi keren ya... karena dia nggak sok asyik tapi dia tepat pakai dialek Makassarnya kapan, dia harus Berbahasa Indonesia kapan, pake Bahasa Inggrisnya kapan. Itu sebetulnya yang kita inginkan. (Wawancara dengan Ibu Nia Soewardi - Direktur Jaringan Prambors Jakarta)

Bahkan untuk radio Prambors Yogyakarta, salah satu syarat menjadi penyiar di radio tersebut adalah harus pula mampu berbicara dalam bahasa Jawa. Ini menandakan bahwa ada keluwesan dalam upaya mengakomodasi penggunaan bahasa Jawa dalam siaran yang dilakukan. Ini terjadi karena tuntutan dari pendengar, yang ternyata melakukan resistensi apabila dalam siaran murni hanya menggunakan gaya bahasa siaran yang ala Jakarta.

Ya itu tadi ... kreatif, gesit, jujur. Itu sebenernya kalo ditanya gak ada yang kreatif gesit dan jujur, gimana sih caranya ? Kita mencoba untuk meberikan persyaratan. Seperti kemarin kami baru buka lowongan. Syaratnya harus bisa bahasa Jawa, kemudian bisa bahasa Inggris, kemudian juga wawasan yang luas. Kemudian yang keempat mudah bergaul, dan yang kelima kreatif. Bagaimana cara mereka untuk kreatif kita lihat langsung karena karena 
prosesnya adalah test. Test pertama tulisan, kedua test bahasa inggris, test bahasa Jawa, juga wawasan. Bila lolos, langsung interview. Habis interview, kami punya satu test lagi, yakni talent show. Nah di situ mereka harus beratraksi. Mereka mau menunjukkan, mengekspresikan dirinya dengan menyiar, menyanyi, atau melucu atau nge-dance. Terserah deh ... Itu creativity yang mereka di kabin siaran, di sebelah sana ada kreatifitas yang mereka bikin ditempel dikantin. Jadi ee buatlah sebuah creativity, mereka diberi tugas membuat sebuah kreatifitas buatan tangan, bebas apapun, yang temanya adalah Prambors..dan teman-teman bikin.. Di situ kita juga menilai. Jadi temen-temen yang senior membikin training itu menilai dengan nama si ini..seperti apa perkembangan si ini..perkembangannya seperti apa.. terus kita lihat..kita pantau.. Jadi nanti kreatifnya kita tinjau Oh ini.. ini.. The man in the right position.. (Wawancara dengan Michael Hendarman - Program Director Prambors Yogya)

Pernyataan serupa juga dinyatakan oleh pengelola Radio Prambors Solo yang menyatakan bahwa penggunaan gaya bahasa siaran dengan menggunakan dialek lokal (dialek Jawa) tidaklah diingkari secara mutlak. Penggunaan gaya bahasa siaran dengan dialek Jawa tetap diakomodasi untuk untuk mengeliminir resistensi dari pendengar akan gaya bahasa siaran yang terasa sangat Jakartacentris.

Dialek Jakarta diperkenalkan juga ... Jadi kalau yang seperti itu sih lebih ke yang disukai. Jadi maksudnya bukan yang patokan yang harus seperti gitu..gitu segala macem begitu.. enggak begitu. Seperti akhirnya waktu kemarin waktu kita siaran pertama kali di Solo. Ada yang sedikit banyak yang ngereject. Jadi mungkin yang ngomong ini pake elo-gue elo-gue gitu.., kan di sini kan ada banyak orang Jakarta-nya juga gitu... Akhirnya pertama kali sih memang konsumsinya adalah AkuKamu gitu ya, Cuma merekanya sendiri juga sering keceplosan. Sudah dikasih tahu.. Ada sedikit penolakan terhadap mereka pada waktu itu. (Wawancara dengan Annas Program Director Prambors Solo)

Adapun bentuk penolakan tersebut dinyatakan langsung ke pengelola radio Prambors via SMS yang masukyang memuat pernyataan resisten terhadap penggunaan gaya bahasa (dialek dan kosa kata) yang ala Jakarta. Di antaranya berbentuk sindiran.

Bentuknya sindirian, ya ... Ada yang bilang : serasa di Jakarta nih..Jadi seperti itu sindiran-sindirannya. Ya ... itu sebenernya slentingan juga buat kita.. Apa sih, jadi manggilnya sepertiAbangsama Non...Jadienggak enak juga.. Jadinya kita enggak enak sendiri sama pemirsanya. Tapi, kalimat yang dipergunakan adalah kamu dan aku. Karena kalimatnya kan lebih deket gitu. Sapaan kawula muda itu juga masih diuji kok. Maksudnya bukan di-reject sih, tapi misalnya; oke kawula muda, kok kawula muda terus sih. Maksudnya adalah ini tuh antara aku dan kamu gitu.. Karena akan lebih personal, lebih deket. Misalnya saya dengerin siaran ini, tiba-tiba ada penyiar yang ngomongnya kamu. Sepertinya aku merasa lebih dihargai sebagai pendengar itu sendiri, meskipun dalam jumlah jamak kan karena banyaknya jumlah pendengar radio. (Wawancara dengan Annas Program Director Prambors Solo)

Selain di radio Prambors Solo, penolakan terhadap gaya bahasa siaran yang Jakartacentris ternyata juga terjadi di pendengar radio Prambors Yogya. Ini terjadi ketika pada awal siarannya, radio 
Prambors Yogya banyakmerekrut penyiar remaja Yogyakarta yang sebenarnya berasal dari Jakarta. Ini dilakukan dengan keyakinan, bahwa remaja Yogyakarta asal Jakarta ini mampu melakukan siaran dengan bahasa Indonesia yang baik dan benar. Namun dalam realitasnya dialek yang keluar akhirnya terasa bernuansa Jakarta. Ini memunculkan penolakan bagi pendengar Prambors Yogya yang asli Yogyakarta.

Kebijakan rekruitmen pun dirubah. Rekruitmen penyiar kemudian mulai melibatkan remaja Yogyakarta. Namun kemampuan untuk dapat melakukan siaran dengan bahasa Indonesia yang baik dan benar tetap diberlakukan. Dengan demikian nuansa lokal bisa diperdengarkan untuk pendengar remaja Yogyakarta. Penyiar Prambors Yogya juga mengakui, ada beberapa kesulitan apabila gaya bahasa siaran ala Jakarta langsung dengan serta merta diterapkan di radionya. Dirasakan ada yang tidak pas dengan karakteristik daerah Yogya, sehingga dari sisi kosa kata seperti sapaan "elo-gue" tidak berani untuk digunakan.

Bahasa itu juga... Dulu mungkin kita dibilang "kamu", sekarang lebih banyak mendengarkan "loe". Banyakan dipake-nya seperti itu, tapi kalau di sana masih pakai "loe gua", tapi kalau di Jogja saya sangat tidak berani untuk menggunakan bahasa "elo - gua". Sekarang ternyata memang beda, suasananya memang beda. (Wawancara dengan Michael Hendarman, Program Director Prambors Yogya)

Di Prambors Yogya, penggunaan gaya bahasa siaran lokal (dialek Jawa dan kosa katanya) ternyata juga tidak tabu untuk dibawakan dalam siaran di Prambors. Demi menjaga hubungan yang baik dengan pendengarnya, Prambors Yogya berusaha juga mengakomodasi gaya bahasa siaran lokal ini agar tidak ditinggalkan oleh pendengarnya. Dengan demikian penggunaan gaya bahasa siaran lokal malah dipandang menguntungkan untuk digunakan dalam siaran di radio Prambors Yogya.

Nggak ... sama sekali nggak tabu ... malah menguntungkan sekali. Bahkan saya sempat di papan tulis kita menulis sering gunakan bahasa Jawa, Dilarang ngomong elo-gue gitu sampai kita tulis. Karena untuk membuat pakem itu kita paham kebuituhan orang Jogja itu, kita tidak boleh meninggalkan mereka salah satu sumber dana terbesar. Memang tidak kelihatan namun yang terjadi feedback-nya adalah mau enggak mau iklan juga banyak. (Wawancara dengan Michael Hendarman Program Director Prambors Yogya)

Dari pengelola radio Prambors yang berpusat di Jakarta, walaupun penggunaan gaya bahasa siaran memiliki standar tertentu (dengan dialek dan kosa kata Jakarta), namun penggunaannya tidak berlaku secara mutlak. Semuanya diserahkan pada jaringan radio Prambors yang berada di daerah. Jika memang nyaman digunakan dengan gaya bahasa siaran yang ala Jakarta dan pendengar bisa menerima, maka diperkenankan untuk digunakan. Tetapi sebaliknya bila ternyata dirasakan kurang nyaman dan juga ada penolakan dari pendengar, diperkenankan pula digunakan gaya bahasa siaran lokal.

Sebetulnya begini. Kami memang jaringan. Sekarang Prambors ada di delapan kota di berbagai provinsi. Ada yang di Jawa ... Jawanya aja berbeda - beda, ada yang di Jogja, ada yang di Solo kota yang lebih kecil, ada yang Surabaya, ada yang Bandung ... Di luar Jawa, 
ada di Medan, di Makassar. Jadi ... strategi awal ketika kita membentuk jaringan ini, bahasa, kita tidak mau men-Jakarta-kan kota lain, dalam arti dengan sengaja. Jadi, sebetulnya kami tidak memaksakan ... misalnya yang paling jelas adalah loe-gue. Nah pertama tidak memaksakan. Tapi seandainya para penyiar di sana merasa nyaman dengan membahasakan dirinya dan pendengarnya loe-gue, dan bisa diterima oleh pendengar...silakan saja dipakai ! Jadi sebetulnya, gak ada pembatasan yang sangat ketat ... ya do and doesnya gitu ya...mereka harus mendapat feel lokalnya... OK, misalnya Medan. Mereka kasih masukan pengurus radio di sana. Medan tidak bisa pakai loe-gue. Jadi apa yang diterapkan? Bahasa sehari - harinya aku kamu. Silakan pake.. gitu kan ya ? Nah, di Jogja mendua khan ? Akhirnya kita menemukan bahwa penggunaan kosakata loegue itu bukan secara umum berlaku ... Orang Jogja nggak mau pakai semua, atau orang Medan nggak mau pakai semua, Surabaya sebaliknya malah pakai semua, gak gitu... Jadi rupanyanya sangat personal itu. Ketika Daginks-Desta ngomong loe-gue ... diterima karena mereka punya potret yang lengkap, khan ? Ooo... Daginks-Desta memang biasa loe-gue dan ketika ngomong juga nyaman ... gitu khan ya ? Tapi siapa misalnya, penyiar Jogja ... Renata ... Renata nggak bisa ... nggak biasa loe-gue, sehingga ketika didengar sama pendengar loe-gue jadi aneh....Jadi, khan bahasa itu ungkapan ekspresi yang paling nggak bisa pura - pura, kan ya? Kalau dia tulus ya kedengeren tulus, tapi kalo gue bletak bletuk jadi nggak enak ya ? Begitu juga pendengar ... jadi penyiar udah punya feeling .... kalau misalnya dia ngomong lewat telpon dengan pendengar Jogja yang tidak biasa ngomong loe gue....Tapi kadang - kadang pendengar punya persepsi...wah harus ngomong loegue supaya dipandang sebagai anak gaul, gitu khan ya ... ? Nah, penyiarnya ketika punya feeling itu tidak mbelit loe-gue, tapi aku-kamu ! Gitu ... Jadi aksi reaksi sebetulnya ketika eksekusi terjadi. Kita gak punya pakem yang sangat.....apa namanya ? tegas ya ? Mainkan feeling ...Mainkan penilaian..yang apa..terjadi pada saat eksekusi itu berlangsung . ...seperti itu ... ! Kalo memang seseorang udah trima loe gue, ya ngomonglah itu, gitu ya ..kalo belum ya jangan dipaksain.. itu memang bukan sebuah pakem.. ngomong loe gue..Sebenarnya bahasa resmi Prambors tu aku.. ehh..kamu kalo untuk pendengar. Gimana kabar kamu? gitu ya ? Kamu tuh juga singkatan dari Kawula Muda. Gitu khan ..Ehem ... Tapi rupanya ya secara alamiah kalo anak Jakarta hari ini jarang yang pake kamu. Jadi ya makin ke sini ya makin jarang kamu itu diucapkan. Ehem..ee (agak tersendat ) dalam monolog juga dalam dialog. Tapi ee.. kadang - kadang beberapa penyiar masih mengotrol penggunaan kamu terutama di monolog ... tapi ketika dialog lebih banyak menggunakan loe-gue. Tapi ketika usianya lebih muda, gitu ... atau lebih tua, denger khan ya ... ? misalnya eh kamu umurnya berapa ? aku 15 ..lha dia bahasanya kamu, karena penyiar umunya 20-an. Tapi kalo udah sejajar loe gue. Jadi aksi reaksi yang ..yang..berlangsung e..berbeda beda. Ada yang aku kamu, ada yang loe gue, ada saya kamu. (Wawancara dengan Ibu Nia Soewardi - Direktur Jaringan Prambors Jakarta)

Dengan demikian, penggunaan gaya bahasa siaran sebenarnya diserahkan pada otoritas pengelola Prambors daerah, seperti yang ada di Bandung, Semarang, Yogyakarta, Solo, Surabaya, bahkan hingga Medan dan Makassar. Bila dirasakan nyaman, diperkenankan untuk menggunakan. Namun bila dirasakan tidak nyaman, diperkenankan 
untuk menggunakan gaya bahasa lokal untuk tetap menjaga relasi antara penyiar dengan para pendengarnya.

Di level penyiar Prambors Jakarta pada dasarnya tidak selalu setuju jika kemudian konsep radio anak muda selalu identik dengan Jakarta. Karena masing-masing daerah akan memiliki kekhasannya sendiri-sendiri, yang akan saling berbeda satu dengan yang lain.

Gaksih,.gue gak setuju banget. Karena kayak e..kayak contoh yang paling deket, gue suka banget lihat konsep anak Bandung gitu..karena menurut gue setiap anak daerah tu punya ciri khas masing - masing..Kenapa harus kiblatnya ke Jakarta kalau memang loe bisa mempertahankan style loe seperti itu kenapa gak ? Siapa tahu malah suatu saat daerahnya dia yang jadi trendsetter nya khan? Karena kalo semuanya kiblatnya ke Jakarta ee..ya akhirnya udah gak ada variasi lagi..gitu..justru khan yang bikin kita seru, kayak ketika gue ke Bandung, ternyata gue miss,..oh ternyata pergaulan Bandung itu begini.. mereka itu lebih nyeni,..mereka tuh bisa menjadikan Dago yang turun ngamen, santai.Anak Jakarta mana ada yang kayak gitu..Soalnya kalo di Bandung yang kayak gitu - gitu sudah biasa. (Wawancara dengan Panda Penyiar Prambors Jakarta)

\section{Upaya-Upaya Jakartanisasi oleh Manajemen Siaran}

Di sisi lain, walaupun ada upaya untukmengakomodasi gaya bahasa siaran lokal bukan berarti pula gaya bahasa siaran lokal terus menerus diakomodasi. Upaya untuk merekayasa gaya bahasa siaran ala Jakarta tetap pula diupayakan. Di Prambors Solo, beberapa penyiar yang dirasakan memiliki gaya bahasa bicara yang sangat lokal (medok Jawa), tetap diupayakan untuk juga bisa menerima teratment khusus agar gaya bahasa siaran di radio juga tidak terasa sangat kental dengan nuansa lokal. Bentuk-bentuk dari treatment tersebut misalnya adalah dengan cara memasangkan seorang penyiar yang memiliki gaya bahasa yang sangat lokal dengan penyiar lain yang lebih senior dan sudah memiliki gaya bahasa siaran dengan karakter standar dari radio Prambors. Diharapkan lamakelamaan gaya bahasa siaran lokal atau dialek lokal tersebut dapat semakin diminimalisir.

Selain itu treatment yang dilakukan adalah dengan membiasakan penyiar tersebut untuk meminimalisir penggunaan gaya bahasa lokal dalam perbincangan atau pergaulan kehidupan sehari-hari. Harapannya adalah juga untuk meminimalisir agar gaya bahasa siaran lokal agar tidak menjadi dominan ketika penyiar tersebut melakukan siaran di radio Prambors. Dan untuk beberapa kasus, upaya ini ternyata berhasil dilakukan.

Dulu, penyiar kami, Rory itu tipikalnya sangat Tegal. Jadi penyiar kita namanya kan Rory.. Sangat Tegal.. Tipikal suaranya besar yang microphonis banget.. Trus tipikal siaran-siaran yang sangat formal. Lama-kelamaan kita racuni nih. Kita kasih tandemnya adalah penyiarpenyiar senior yang slengekan. Akhirnya dia dapet juga.. dia lepas..lepas..lepas..lepas..lepaskan medoknya. Lambat laun dia malah menjadi.. lumayanlah daripada dia waktu kita pertama kali dia dapet gitu. Dulu sangat medok sekali. Tapi akhirnya coba deh kesehariannya ngomong bahasa Indonesia jangan bahasa Jawa terus. Dia masuk ke sini kita biasanya langsung menyapa dengan bahasa Indonesia. Dari minimal selamat pagi.. nah itu kan udah lumayan bagus gitu kan. Habis itu, ngobrol..ngobrol..ngobrol.. ngobrol..ngobrol...Ayo..ayo..ha..ha.. ha.. Ya, karena itu meminimalisir 
gitu. Bahkan kita yang Prambors Jogja pun menggunakan bahasa Jawa juga kan, yang waktu angkringan itu. Bahkan yang kita dapet dari prambos Jogjapun menggunakan bahasa jawa juga kan pada waktu angkringan itu. Jadi ada 2 tipikal kan pada waktu itu. Nah kita tidak meninggalkan tapi ini lho ... kita kan Prambos jakarta gitu... Jadi bisa di buat main-main sebenarnya. Maksudnya main-main adalah permainan karakter yang lebih kita dapetin. Tapi harapan kita sih gak terlalu medok-medok banget lah .karena nanti lepas dari platform juga, toh .... (Wawancara dengan Annas - Program Director Prambors Solo)

Atau walaupun terdapat calon penyiar yang ternyata masih memiliki gaya bahasa siaran yang relatif kental dengan nuansa lokal, maka salah satu prasyarat untuk diterima sebagai penyiar di jaringan radio Prambors daerah, penyiar tersebut haruslah memiliki kelebihan (added values) dengan gaya bahasa siarannya tersebut. Misalnya mampu bermain peran di beberapa acara yang memang membutuhkan penyiar yang harus mampu bermain peran. Di sini berarti bila mempertahankan gaya bahasa siaran lokal bisa jadi bukan merupakan persoalan. Namun gaya bahasa siaran tersebut harus tetap memiliki nilai jual dalam siaran radio.

Tapi kalo seperti yang saya bilang tadi kalo misalnya dia punya value yang lebih dari kemedokannya terbentuk hal-hal yang lucu karena kan kita siarannya..siaran yang seru nih kita bikin show bahkan untuk time plan pun kita bikin yang " lu mau ngapain aja di jam ini ? "gitu-gitu kan.. jadi kita akan bisa merasa bahwa kalo itu bisa menjadi value dan dia lucu.kita akan tawarin dia untuk bisa menjadi karakter itu aja...usually ada orang kampung datang ke kota Solo dengan membawa kemedokannnya tapi kedengarannya lucu, kalo misalnya dia .... oh ini medok ... tapi lucu tapi pinter itu kita ambil. Tapi kalo_misalnya medok keliatan bodoh mending enggak deh... (he..he..he..) iya kan? (Wawancara dengan Annas - Program Director Prambors Solo)

Pernyataan senada juga sempat dilontarkan oleh salah seorang penyiar Prambors Jakarta (Panda), bahwa penggunaan dialek lokal masih sahsah saja. Namun demikian tetap penggunaannya tidak diperkenankan untuk menjadi dominan. Artinya penggunaan dialek lokal hanya bersifat sebagai selingan semata.

Sebenarnya gak pernah dikasih tau secaralangsung..Cumagini,mungkin karena Prambors radio lama ya ... udah 30 sekian tahun .... jadi ... tanpa disadari dengan mendengar penyiar - penyiar jaman dulu kita udah punya pakem - pakem tersendiri gitu ... yang pasti gak boleh cacat vokal ... kenapa ? Karena kalo cacat vokal terlalu parah ... kalo ngomong r misalnya agak - agak ketelan,.. dulu ada penyiaran kayak begitu, gak masalah selama masih artikulasi jelas . Eee..tapi terus buat dialek juga karena kita kan jangkauannya nasional, yang dengerin kita kan berbagai ras, berbagai suku bangsa, .jadi alangkah baiknya kalau ya kita pake bahasa Indonesia ... tapi kalo mau mengeluarkan dialek buat lucu - lucuan kayak Jawa, mau Padang, kadang - kadang gue yang sok sok dipelo-peloin Cina - tuh nggak masalah ... asal itu hanya menjadi bumbu di siaran, bukan utamanya gitu .... Ntar kalo gue sokngomongnya pake Jawanya bledag-bledug banget, orang yang ngedengerin juga khan ... Busyet dech penyiar, Jawa banget kayak jual jamu aje .... misalnya gitu.. tapi kalo bahasa baik.. yang baik dan benar ya gak lah..se-gaknya - gaknya..ya iye deh Itu khan kayaknya jadinya formal banget... gitu..yang penting ini kali ya..lebih 
ke dialek ya..gak boleh yang terlalu daerah.,,gitu .. Pokoknya dengernya harus netral - netral aja. (Wawancara dengan Panda - Penyiar Prambors Jakarta)

Adapun alasan utama meminimalisir penggunaan gaya bahasa siaran lokal (dialek dan kosa kata lokal) khusus untuk Prambors Jakarta adalah karena Prambors Jakarta memiliki siaran berskala nasional pada jam-jam tertentu. Sehingga gaya bahasa siaran lokal sebisa mungkin dihindari. Ada kekhawatiran bahwa penggunaan gaya bahasa siaran dari daerah tertentu tidak bisa diterima di daerah lainnya.

Iya sih ... kalau bisa alangkah baiknya jangan ada dialek daerah tertentu...dan lagi - lagi kita kan skalanya kan dah luas gitu .. dengerin Jabodetabek apalagi kalo yang dengerin..kayak Daginks-Desta,... itu kan dah skala nasional... Gak mungkin kita pake dialek tertentu gitu..Karena diciptakan Bahasa Indonesia untuk mempersatukan semuanya ... (Wawancara dengan Panda - Penyiar Prambors Jakarta)

Selain itu upaya untuk menjaga kekhasan gaya bahasa siaran Prambors tampaknya sudah dilakukan secara tidak sadar dari rekruitmen penyiar. Walaupun di bagian atas disebutkan bahwa rekruitmen penyiar berupaya untuk mengadopsi remaja-remaja daerah, namun pada akhirnya penyiar yang tersaring hingga mendekati final adalah calon penyiar yang memang sudah memiliki tipikal sebagai orang Jakarta, baik memang orang Jakarta ataupun orang daerah yang sempat mengenyam kehidupan di Jakarta. Ini diyakini karena orang Jakarta memiliki gaya bahasa bicara yang memang sesuai dengan yang dibutuhkan radio anak muda seperti radio Prambors.
Nah, sebenernya gini sih. Waktu itu kan kita buka lagi banyak nih, jadi untuk .masuk ke Prambors gitu kan. Tadi mereka sudah apply. Kebetulan waktu itu masih banyak sekali sekitar dua ratusan lebih yang masuk. Akhirnya kita saring nih. Salah satu tes-nya adalah kita hadapin kepada satu benda. Tergantung milih apa gitu. Kalo misalnya di dalam kocokan itu kan ..ee.. kita sih lebih ke kelancarannya dia ngomong gitu. Satu, kebutuhan orang Jakarta itu ngomong Indonesia-nya tuh sudah enak. Kedengerannya juga enak. Yang kedua secara pilihan bahasa mereka lebih kaya, karena mereka sering menggunakan bahasa Indonesia sehari-hari. Tidak menutup kemungkinan untuk anakanak yang ada lokalnya yang ada di Solo sih sebenernya tuh. Bahkan saya bukan orang Jakarta sih sebenernya gitu. Terus mungkin karena pergaulannya banyak dengan temen-temen yang ada di Jakarta dan luar Jakarta, atau mungkin luar dari Solo, jatuhnya ketika ngomong tuh kita jadi enak gitu. Sebenernya dari sini sih dari kelancaran ngomong dulu sih. (Wawancara dengan Annas - Program Director Prambors Solo)

Penyiar Prambors Yogya pun secara tidak sadar tersaring dari para remaja yang pada dasarnya memiliki kebiasaan sebagai remaja yang dari kalangan keluarga menengah dan menengah ke atas. Seperti yang dinyatakan oleh salah satu penyiarnya, Dita. Selain juga bukan merupakan remaja Yogya, sejak kecilnya pun lama tinggal di Timur Tengah (Jeddah-Arab Saudi) karena mengikuti orang tuanya. Kebiasaan dengan aktifitas klub malam (clubbing) bukan merupakan hal yang baru. Namun pada dasarnya memang sudah menjadi aktifitas yang digeluti sebelum bergabung dengan Prambors Yogya.

Soalnya memang sudah suka 
kayak gitu (clubbing). Makanya saat dengerin Prambors, karena cocok juga gitu. Masuk ke Prambors tuh juga karena cocok juga ya dengan anak-anak yang kayak begitu juga. Sebenernya memang sudah..sudah ini juga sih... (Wawancara dengan Dita - Penyiar Prambors Yogya)

Ini juga dikuatkan dengan pernyataan penyiar Prambors yang lain bahwa rata-rata tidak ada perubahan perilaku yang berarti dari para penyiar Prambors, antara periode waktu sebelum dan sesudah menjadi penyiar. Artinya bahwa sebelum mereka menjadi penyiar Prambors, pada dasarnya mereka tetap menjalankan aktivitas seperti biasa sebagai remaja kelas menengah dan menengah ke atas pada umumnya, termasuk dalam hal pemilihan teman bermain.

Temen gue sih gak berubah....tapi sempet yang..ah males ah ngajak loe, kemana - mana susah, kemana - mana nolak melulu ... Bukannya nolak sih, Cuma memang dulu khan Prambors training 6 bulan ... itu tiap hari ... dari jam 4 ampe jam 8 tiap hari, jadi otomatis khan kalo nongkrong sudah gak ada waktunya gitu..kalo malem udah ngantuk karena besok paginya masih kuliah.. paling perubahannya di situ sih ... Sekarang..e...malah lebih - lebih lagi..karena dulu pas awal - awal khan kerja masih siaran tapi setahun gue siaran khan ada aktivitas lain.. ya nge-MC lah. Ya..sempet jadi presenter di TV lah gitu..jadi ya..kalo mau ketemu ma temen ya..sebulan sekali aja dah bagus (nada turun )..Tapi khan untungnya gini..ketika gue di atas phone, maksudnya gue kerja..ya penyiar - penyiar yang lain ya temen gue juga..Jadi gue pun kalo bekerja di Prambors, gue gak berasa kayak gue harus masuk kantor, gue harus kerja..gue malah biasanya kayak maen - maen tapi serius.. gitu. Untuk pertemanan dengan temen-temen SMA ... tetep ... dengan temen - temen SMA gue dulu sampe sekarang pun kalo mau keluar kota ,nongkrong masih sama mereka. gitu..gak ya berubah total langsung temenan ma siapa ..gitu ... gak.. gue masih tetep temenan dengan temen SMA gue..ampe sekarang. (Wawancara dengan Panda - Penyiar Prambors Jakarta)

\section{Pembahasan}

Pendekatan ekonomi politik media sebenarnya sangat memperhatikan bentuk-bentuk komoditi dalam komunikasi melalui isi media. Di sini terlihat bahwa proses komodifikasi dalam komunikasi termasuk penciptaan pesan dari sejumlah data menjadi produk-produk yang laku dijual (Mosco, 1996: 146). Pendekatan Marxian melihat bahasa selain sarana komunikasi juga menjadi sarana produksi material bagi industri komunikasi. Dalam kasus penelitian ini, asumsi awalnya adalah bahwa gaya bahasa penyiaran juga merupakan sarana produksi material bagi industri komunikasi yang bernama radio Prambors. Melalui proses komodifikasi, gaya bahasa penyiaran ini dibentuk sedemikian rupa sehingga menjadi sesuatu yang laku jual. Maka terciptalah gaya bahasa penyiaran radio Prambors yang ala Jakarta.

Kemudian asumsi berikutnya adalah, pada tataran produksi, hal yang juga menentukan dalam kerangka ekonomi politik media adalah kerja organisasi, salah satunya adalah bentuk kerja rutin media (media routines), seperti dikemukakan oleh Shoemaker dan Reese (1996 : 112-113), yaitu praktek organisasi pada industri media yang mempengaruhi isi media. Artinya ketika radio Prambors memutuskan untuk memiliki beberapa jaringan di daerah, 
gaya bahasa penyiaran radio Prambors yang ala Jakarta menjadi sesuatu yang baku yang juga harus diterapkan di seluruh jaringan radio Prambors. Dan ini tentunya dilakukan melalui mekanisme rutinitas media. Dalam pendekatan ekonomi politik media, teks-teks media termasuk dalam hal ini adalah gaya bahasa penyiaran radio Prambors yang ala Jakarta, merupakan bagian dari produksi industri media dalam logika industri yang kapitalistik. Grossberg (1998: 179180) lebih jauh menjelaskan bagaimana sebuah teks media direproduksi dalam mata rantai industri media. Teks media dalam industri media hadir sebagai sebuah representasi (re-presentation) yang berarti direproduksi kembali. Ini artinya penyiar sebagai garda depan radio Prambors, baik yang berada di pusat maupun di jaringannya di beberapa daerah, memiliki peran yang sentral dalam proses produksi komunikasi. Ini supaya para pendengar radio Prambors merasakan gaya bahasa penyiaran yang ala Jakarta sebagai sesuatu yang wajar dan alami.

Pertanyaan selanjutnya adalahjika gaya bahasa penyiaran Prambors yang ala Jakarta tersebut memang menjadi standar yang harus diterapkan di seluruh jaringan radio yang ada di pelbagai daerah, bagaimana gaya bahasa penyiaran ini kemudian diperkenalkan kepada penyiar daerah yang berkemungkinan memiliki gaya bicara yang bernuansa lokal karena adanya kedekatan secara geografis dengan tempat tinggalnya ? Rutinitas media yang berlangsung pada manajemen radio Prambors, mulai dari pusat sampai dengan yang ada di jaringannya, tentu saja akan berupaya dengan berbagai cara agar gaya bahasa penyiaran yang ala Jakarta ini tersosialisasi dengan baik dan dapat diterima secara alami terutama di kalangan penyiar radio Prambors yang berada di daerah. Pendekatan ekonomi politik media melihat hal seperti ini sebagai kerja ideologi.

Raymond Williams (1996: 166) menyatakan bahwa dalam ideologi, kelas penguasa akan mengontrol saranasarana utama yang yang menjadi sarana penyampaian dan penyebaran ideologi pada masyarakat, dimana hal tersebut dapat membuat kelas pekerja melihat subordinasi sebagai hal yang 'alami' dan dibenarkan keberadannya. Kesadaran sosial ini akan selalu dipelihara oleh kelas dominan dan subordinasi yang terjadi akan tampak "alami" dan "normal" serta dianggap benar padahal disitulah terdapat kepalsuan. Dengan demikian apabila ini terjadi di radio Prambors artinya bahwa pihak manajemen radio selaku kelas dominan akan selalu berupaya meyakinkan penyiarnya bahwa menguasai gaya bahasa penyiaran yang ala Jakarta adalah sesuatu yang alami dan normal. Ini dilakukan melalui pelatihanpelatihan yang diberikan, termasuk adalah adanya treatment dan sanksi apabila tujuan ini tidak tercapai.

Namun dalam temuan penelitian di lapangan ternyata proses ini tidaklah berlangsung mulus. Penolakan terhadap gaya bahasa penyiaran yang ala Jakarta sebenarnya tidak datang utamanya dari kalangan penyiar, namun penolakan justru datang dari kalangan pendengar dari jaringan radio Prambors yang berada di daerah. Seperti di radio Prambors Solo misalnya, gaya bahasa penyiaran yang ala Jakarta yang diterapkan pada masa-masa awal berdirinya, mendapat resistensi kuat dari kalangan pendengarnya. Sindiran via beberapa Short Message Service (SMS) yang datang di radio tersebut menunjukkan ketidakpuasan pendengar Prambors di Solo atas gaya bahasa siaran yang 
Jakartacentris. Untuk radio Prambors Yogya tidak jauh berbeda. Pengelola radio Prambors Yogya menyatakan bahwa penggunaan gaya bahasa penyiaran yang terlalu Jakartacentris, seperti penggunaan kosa kata "eloe-gue", ternyata tidak dapat diterima secara mulus di telinga pendengarnya karena diyakini pendengar tidak sesuai dengan suasana Yogya.

Kondisi ini tentu memaksa manajemen siaran radio Prambors untuk mengkaji ulang kebijakan penggunaan gaya bahasa siaran yang ala Jakarta untuk terus diterapkan di jaringan radio Prambors daerah. Radio Prambors akhirnya membuka diri untuk gaya bahasa siaran lokal (dialek dan kosa kata lokal). Ini dilakukan sebagai upaya win-win solution antara manajemen radio Prambors dengan para pendengarnya di daerah. Ini tentu juga adanya kesadaran ternyata gaya bahasa siaran lokal ternyata juga memiliki nilai jual. Untuk radio Prambors Yogya, kebijakan ini bahkan berimbas pada salah satu syarat penerimaan calon penyiar, yakni bahwa calon penyiar radio Prambors Yogya harus bisa berbahasa Jawa.

Temuan-temuan ini sebenarnya juga bukan berarti menunjukkan kelemahan pendekatan ekonomi politik dalam upaya memahami perilaku media. Media massa dengan pendekatan pasar pada dasarnya memang memiliki beberapa sifat, yakni bahwa media yang menggunakan pendekatan pasar pasti bersifat responsif terhadap situasi. Selain itu pula media massa dengan pendekatan ini selalu akan bersifat flexibel. Dan yang terakhir media massa dengan pendekatan pasar akan selalu berupaya melakukan inovasi (Croteau dan Hoynes, 1997). Media massa responsif terhadap berbagai situasi artinya bahwa media massa dituntut untuk selalu tanggap terhadap situasi yang ada, artinya tanggap akan keinginan pasar dengan harapan cepat untuk diperhatikan oleh audiens. Media massa bersifat fleksibel artinya media massa akan selalu fleksibel baik dalam hal manajemen organisasi dan penentuan isi pesan media. Media massa selalu berinovasi artinya media massa harus selalu inovatif, dari sisi isi program misalnya, agar tetap dapat bertahan.

Dengan demikian ini mirip dengan apa yang dilakukan oleh manajemen radio Prambors baik di Jakarta maupun yang berada di jaringannya di daerah. Diakui oleh manajemen radio Prambors sendiri bahwa pada dasarnya radio Prambors adalah bagian dari upaya bisnis dari para pengelolanya, bahkan sejak Prambors berdiri. Artinya Prambors juga sangat memperhitungkan masalah profit (untung dan rugi) dalam operasional siarannya. Itu pula yang mendorong Prambors untuk masuk dalam jaringan radio yang lebih besar, Masima Radionet bersama dengan radio Female dan radio Delta yang juga memiliki beberapa jaringan di daerah.

Adanya penolakan pendengar yang kuat terhadap gaya bahasa siaran radio Prambors yang ala Jakarta di beberapa jaringan radio Prambors di daerah segera direspon oleh pengelola manajemen radio Prambors. Ini dilakukan dengan tidak memaksakan penggunaan gaya bahasa siaran tersebut dalam siaran radio terutama yang ada di jaringan radio Prambors di daerah. Ini berarti manajemen radio Prambors tanggap terhadap apa yang menjadi keinginan para pendengarnya. Kemudian dengan mengakomodasi penggunaan gaya bahasa lokal dalam siarannya menunjukkan pengelola radio Prambors bersifat fleksibel dalam penentuan materi 
siarannya. Bahkan untuk radio Prambors Yogya, penguasaan bahasa Jawa menjadi salah satu syarat untuk dapat diterima sebagai penyiar Prambors. Dan akhirnya ketika manajemen radio Prambors di daerah pun menciptakan programprogram siaran yang berbasis pada gaya bahasa siaran lokal, seperti program Angkringan di radio Prambors Yogya, menunjukkan bahwa Prambors pun berupaya untuk inovatif menciptakan program-program yang berbasis pada lokalitasnya. Tentu ini semua dilakukan oleh pengelola manajemen radio Prambors agar tidak ditinggalkan pendengarnya.

Upaya-upaya untuk melakukan Jakartanisasi yang kemudian diakhiri dengan upaya tetap mengakomodasi gaya bahasa siaran lokal di jaringan radio Prambors yang terdapat di daerah mengingatkan pula pada konsep globalisasi dan glokalisasi. Globalisasi merupakan penyebaran kebiasaankebiasaan yang mendunia, ekspansi hubungan yang melintas antar wilayah, organisasi dari kehidupan sosial pada skala global, dan pertumbuhan dari sebuah kesadaran global bersama (Ritzer, 2006; 96). Sedangkan glokalisasi dapat didefinisikan sebagai interpenetrasi global dan lokal yang memberikan hasil unik dalam wilayah geografis yang berbeda (Ritzer, 2006; 98).

Dengan demikian apa yang dilakukan oleh pengelola manajemen radio Prambors Jakarta untuk berupaya mempertahankan gaya bahasa siara ala Jakarta di jaringan radio Prambors daerah seirama dengan konsep globalisasi di tingkatan wilayah Indonesia. Upayaupaya tersebut pada dasarnya merupakan penyebaran kebiasaan-kebiasaan yang berlaku di radio Prambors Jakarta kepada jaringannya yang ada di daerah.
Namun karena upaya-upaya ini tidak berjalan lancar, maka strategi pun berubah menjadi glokalisasi, bagaimana akhirnya jaringan radio Prambors di daerah tetap berupaya mengakomodasi gaya bahasa siaran lokal dalam rangka mempertahankan eksistensi di kalangan pendengar lokalnya.

\section{Simpulan}

Upaya pengelola manajemen siaran untuk mewujudkan keseragaman dalam gaya bahasa penyiaran di kalangan penyiar yang berada di jaringan Prambors daerah ternyata tidaklah berjalan mulus. Walaupun secara teoritis dimungkinkan melalui penjelasan pendekatan ekonomi politik media, namun dalam kenyataannya di lapangan menemui beberapa kendala yang signifikan menghalangi upaya tersebut. Kendala yang datang justru bukanlah dari lingkungan internal organisasi yakni para penyiar. Namun kendala paling nyata justru datang dari para pendengar Prambors sendiri yang ada di berbagai daerah, misalnya Yogyakarta dan Solo. Resistensi pendengar menjadikan pihak manajemen penyiaran radio Prambors melakukan upaya bargaining guna tetap menjaga eksistensi radio di mata pendengarnya.

Secara teoritis, pendekatan ekonomi politik media sebenarnya memungkinkan adanya upaya-upaya penyeragaman gaya bahasa penyiaran ala Jakarta di jaringan radio Prambors daerah. Ini tentu melihat karakteristik dari radio Prambors sendiri yang secara nyata menggunakan pendekatan industri (pasar) dalam pengelolannya. Dengan demikian, sebenarnya fenomena ini seiring dengan apa yang diyakini oleh pendekatan ekonomi politik media tentang bagaimana logika industri kapitalisme. Diyakini oleh 
pendekatan ini bahwa karena menguasai modal, yakni alat-alat produksi dan sumber daya manusia (misalnya penyiar), pihak pengelola manajemen radio Prambors tentu mampu memaksimalkan modal tersebut untuk kemudian meraih keuntungan. Penguasaan sumber daya manusia, seperti halnya penyiar, dilakukan tidak dengan cara-cara kekerasan. Ini dapat dilakukan melalui mekanisme kerja ideologi, hegemoni, dan interpelasi, termasuk dalam hal ini adalah bagaimana mensosialisasikan penggunaan gaya bahasa siaran yang ala Jakarta.

Namun kesemua itu ternyata menemui kendala berarti. Bukan dari dinamika internal organisasi, yakni resistensi dari dari kalangan penyiar terhadap "pemaksaan" gaya bahasa siaran yang dilakukan oleh pengelola manajemen Prambors. Tetapi kendala justru datang dari para pendengar Prambors sendiri yang berada di daerah. Pendengar selaku audiens ternyata merasa tidak nyaman apabila mendengarkan siaran Prambors terlalu menggunakan gaya bahasa yang Jakartacentris. Ungkapan protes dalam bentuk sindiran via short message service (SMS) yang terjadi di radio Prambors Solo membuktikan resistensi ini. Peristiwa ini tentu memaksa pengelola manajemen Prambors untuk berpikir ulang. Ini dilakukan dengan tetap mengakomodasi gaya bahasa siaran lokal walaupun dengan batas-batas tertentu (tidak dominan). Kasus radio Prambors Yogya yang mensyaratkan calon penyiar untuk tetap bisa berbahasa Jawa merupakan titik paling ekstrim win-win solution yang dilakukan salah satu jaringan radio Prambors untuk bargaining terhadap para pendengarnya.

Temuan penting ini tidaklah secara otomatis melemahkan pendekatan ekonomi politik media dalam upayanya memahami perilaku media. Karena pada dasarnyaalasandaripengelolamanajemen radio Prambors ketika mengakomodasi gaya bahasa siaran lokal adalah juga untuk menjaga eksistensi radio siaran tersebut di telinga para pendengarnya. Artinya bahwa pada dasarnya upayaupaya menerima gaya bahasa siaran lokal tetap dilakukan dalam rangka kepentingan bisnis, yakni bagaimana gaya bahasa siaran lokal menjadi sesuatu yang tetap menguntungkan secara bisnis. Karena pada dasarnya radio Prambors adalah lembaga ekonomi yang tetap memperhitungkan untung dan rugi.

\section{DAFTAR PUSTAKA}

\section{Buku :}

Agger, Ben (1995). Cultural Studies as Critical Theory, London: The Falmer Press

Curran, Gurevitch and Woolacott, dalam Gurevitch, et.all, The Study of Media: Theoretical Approaches (1982), London: Methuen

Croteau, David and William Hoynes, (1997), Media / Society, Industries, Images, and Audiences, Sage Publication, California

Fiske, John. (1990) Introduction to Communication Studies, $2^{\text {nd }}$ ed. London: Routledge

Grossberg Lawrence (1998). Media Making: Mass Media in a Popular Culture. London: Sage Publications

Hall, Stuart, (1977) Culture, the Media and the Ideological Effect, dalam Mass Communication and Society, Curran et.all., London: Edward Arnold

Larrain, Jorge, (1983) Marxism and Ideology, London: Macmillan

Littlejohn, Stephen W. (2002), Theories of Human Communication, 7th ed., 
California: Wadsworth

Mosco, Vincent (1996). The Political Economy of Communication: Rethinking and Renewal. California: Sage Publication

Macdonell, Diane (1986) Theories of Discourse: an Introduction, Oxford: Basil Blackwell

Mattelart, Armand. (1979) Introduction: For a Class Analysis of Communication dalam Mattelart, A. dan Siegelaub S. (eds.), Communication and Class Struggle (book 1: Capitalism, Imperialism), New York: International General

Muawiyah, Andi, 2000, Peta Pemikiran Marx, LKiS, Yogyakarta

Ritzer, George, 2006, The Globalization of Nothing, Mengkonsumsi Kehampaan di Era Globalisasi, Penerbit UAJY, Yogyakarta

Shoemaker, Pamela J. And Reese, Stephen D. (1996) Mediating The Message, 2nd ed. New York: Longman

Storey, John. (1993) Introductory Guide to Cultural Theory and Popular Culture, New York: Harvester Wheatsheaf

Thompson, John B. (1990) Ideology and Modern Culture: Critical Social Theory in The Era of Mass Communication, Oxford: Polity Press

Majalah :

Majalah Cakram, 2003, Edisi Khusus No. 2 / 2003, Pasang Naik Industri Radio Majalah Cakram, 2005, No. 3 / 2005, Remaja - Pasar yang Seksi

\section{Internet :}

(http://www.uiowa.edu/commstud/ adclass/adage-positioning.html)

(http://www.determan.net/Michele/ mposition.htm)

Kellner (http://www.gseis.ucla.edu/ courses/ed253a/Mckellner/ MCSYM.html)

Klages, http://www.cas.ilstu.edu/ english/strickland/495/ideology. html.

Lye, 1997: URL http://www.brocku.ca/ english/jlye/ideology.html).

\section{Hasil Penelitian :}

Listiorini, Dina (1994). Bahasa Radio Anak Muda di Radio FM di Surabaya. Skripsi tidak diterbitkan, Surabaya.

Herawati, F. Anita dan Setio Budi HH, 2005, Ekologi Media Radio Siaran di Yogyakarta, Kajian Teori Niche terhadap Program Acara Radio Siaran di Propinsi Daerah Istimewa Yogyakarta, Penelitian Dosen Muda, Yogyakarta

\section{Penerbitan Internal :}

Media Scene 2004-2005 oleh Persatuan Perusahaan Periklanan Indonesia (PPPI) 